\title{
GNRHR Gene
}

National Cancer Institute

\section{Source}

National Cancer Institute. GNRHR Gene. NCI Thesaurus. Code C38909.

This gene plays a role in the activation of the phosphatidylinositol-calcium second

messenger signal transduction pathway. 